\title{
Terrorism as Socially Constructed Crime in Indonesia
}

\author{
Heru Susetyo Nuswanto* \\ DOI: https://doi.org/10.22304/pjih.v6n2.a4
}

Submitted: April 15, 2019 | Accepted: September 8, 2019

\begin{abstract}
In the aftermath of Bali Bombing 2002, which is considered the biggest terrorist attack in Indonesia, the Indonesian government launched the so-called 'war against terrorism'. Subsequently, the government established and applied laws on terrorism and formed a special counter-terrorism police squad: The Detachment 88. A state body that coordinates counter-terrorism measures is quickly established, the National Anti-Terrorism Agency (BNPT -Badan Nasional Penanggulangan Terorisme). Therefore, terrorism in Indonesia has been considered a 'big and serious business' since 2002. It also raises a serious question in defining and judging terror crime. Indeed, Indonesia has the law of terrorism since 2002, yet the definition is not very clear. Even in international forum, there is no single and approved definition of terrorism. For instance, an armed group who attacked civilians in Central Sulawesi was named terrorists by the state. On the other hand, a group of militias who attacked and held hostages in Timika, Papua was labelled as an armed criminal group. In Jakarta, there were some bomb threats during 2015 and 2017. Nevertheless, the law enforcement agencies have never named them as 'terrorists', although their actions deserve to be called as 'lone-wolf terrorism'. This paper aims to identify the social construction of terrorism. Terrorism is a term that is used regularly by news media and politicians. Whether its application is impartial or biased is fundamental to a debate. In a society where, international terrorism monopolizes news media and political discussion, there is no greater need than to analyze the boundaries of the term 'terrorism' construction within social processes. One of the serious problems involving terrorism in Indonesia is to define an offense as terrorism. The laws of terrorism are existed. The judgment and conviction to terrorism suspects also have been made in various jurisdictions. Yet, the types of offenses constituted as terrorism are still unclear. Ordinary people, media, opinion makers, and law enforcement officers have socially constructed terrorism and have their own perceptions of terrorism. This condition leads to law uncertainty and, to some extent, it leads to victimization and stigmatization of innocent people because their appearances and social environments have been associated to terrorism. This study employed two approaches: Social construction and guilt by association theories.
\end{abstract}

Keywords: association, socially constructed, terrorism

PADJADJARAN Journal of Law Volume 6 Number 2 Year 2019 [ISSN 2460-1543] [e-ISSN 2442-9325]

* A Lecturer, Bachelor of Law (Universitas Indonesia), LL.M (Northwestern Law School), Master of Social Work (Universitas Indonesia), Ph.D (Mahidol University), herususetyo@ui.ac.id 


\title{
Terorisme sebagai Kejahatan yang Dibangun secara Sosial di Indonesia
}

\begin{abstract}
Abstrak
Setelah Bom Bali 12 Oktober 2002, yang dianggap sebagai serangan teroris terbesar di Indonesia, pemerintah Indonesia meluncurkan apa yang disebut 'perang melawan terorisme'. Undang-undang tentang terorisme segera diberlakukan dan diterapkan secara surut. Polisi Khusus untuk Memerangi Terorisme, yaitu Detasemen 88, dibentuk. Badan khusus untuk mengoordinasikan langkah-langkah anti-terorisme dengan cepat dibentuk, yaitu Badan Nasional Penanggulangan Terorisme atau Badan Anti-Terorisme Nasional. Oleh karena itu, terorisme di Indonesia telah menjadi 'permasalahan yang besar dan serius' sejak tahun 2002. Hal ini pun menimbulkan pertanyaan serius, bagaimana mendefinisikan dan menganggap kejahatan sebagai terorisme? Indonesia memang telah memberlakukan undang-undang tentang terorisme sejak tahun 2002, namun definisi ini tidak begitu jelas. Dan bahkan di forum internasional, tidak ada definisi tunggal, dan satu pihak setuju untuk mengartikan terorisme. Misalnya, sebuah kelompok bersenjata yang menyerang warga sipil di Sulawesi Tengah disebut sebagai teroris oleh negara, sementara kelompok militan yang menyerang dan menahan warga sipil yang disandera di Timika, Pulau Papua dicap sebagai kelompok kriminal bersenjata oleh negara. Di Jakarta Metropolitan, ada beberapa ancaman bom yang dibuat oleh individu pada tahun 2015 dan 2017. Namun demikian, lembaga penegak hukum tidak pernah menyebut mereka sebagai 'teroris', meskipun tindakan mereka pantas disebut sebagai 'terorisme serigala sendirian'. Tulisan ini bertujuan untuk mengidentifikasi sejauh mana terorisme telah dibangun secara sosial. Terorisme adalah istilah yang digunakan secara teratur oleh media berita dan politisi, dan apakah penerapannya tidak berpihak merupakan hal mendasar dalam perdebatan. Dalam masyarakat di mana terorisme internasional memonopoli media berita dan diskusi politik, tidak ada kebutuhan yang lebih besar selain menganalisis sejauh mana istilah 'terorisme' dibangun melalui proses sosial. Salah satu masalah serius yang melibatkan terorisme di Indonesia adalah tentang bagaimana mendefinisikan pelanggaran sebagai terorisme. Undang-undang tentang terorisme ada di sana, keputusan dan hukuman terhadap tersangka terorisme juga telah dibuat di berbagai yurisdiksi, namun, yang merupakan pelanggaran terorisme, masih belum jelas. Masyarakat biasa, media, pembuat opini dan aparat penegak hukum telah secara sosial membangun terorisme dan memiliki persepsi mereka tentang terorisme. Kondisi-kondisi ini kemudian mengarah pada ketidakpastian hukum, dan sampai batas tertentu, viktimisasi dan stigmatisasi kepada orang yang tidak bersalah, semata-mata karena penampilan dan lingkungan sosial mereka telah dikaitkan dengan terorisme. Makalah ini menggunakan dua pendekatan, yaitu konstruksi sosial dan sasa bersalah oleh teori asosiasi.
\end{abstract}

Kata kunci: asosiasi, konstruksi sosial, terorisme.

\section{A. Introduction}

Indonesia is the third largest democracy in the world after India and the United States of America, the world's largest archipelago, and the most populous Muslim 
state with about 227 million Muslims in 2019 of 269.7 million inhabitants. ${ }^{1}$ However, the archipelago is also a home for numerous terrorist attacks. The notable terrorist attacks are, among others, the Bali Bombings (2002 and 2005), the Philippines Ambassador's Residence Bombing (2000), Australian Embassy Bombing (2004), the Jakarta churches bombing (on the Christmas Eve 2000), the J.W. Marriot Hotel Jakarta Bombings (2005 and 2009) ${ }^{2}$, the shooting of civilians in Aceh (2010), the robbery of CIMB Niaga Bank in Medan (September 2010), suicide bombing inside the headquarter of the Cirebon City Police (2011), grenade attacks to police stations in Solo City (2012), suicide bombing inside the headquarter of Poso Regency Police, etc. Since the first Bali Bombing in $2002^{3}$, the Indonesian government has applied harsher policies to combat terrorism. The government faces pressure from internal and external parties to prepare specific regulation to combat terrorism immediately. In 2003, the Indonesian government established the Law Number 15 of 2003 on the Elimination/Eradication of Terrorist Acts. This Law is intended to protect victims and their families from the criminal acts of terrorism.

The massive war against terrorism conducted by Indonesian law enforcers has also created problems. The problems, among others, include arbitrarily arrest, arbitrarily detention, wrongful arrest, and wrongful detention. In some cases, law enforcement officers arrested suspects solely based on sloppy allegation, involving labelling and suspect's guilty feeling by association approach.

For instance, Ragil Sri Hastuti, a wife of a terrorist suspect, was at home with her children when the Special Detachment 88, the Anti-Terrorist Unit Police, raided her house, arrested and shot her husband, Joko a.k.a. Anang Mujadid. Subsequently, the police destroyed the house. Her children were deeply depressed and traumatized. Her children could not see people wearing police uniform afterwards. $^{4}$

In the raid of Pondok Pesantren (Traditional Islamic Boarding School) Al Muaddib, Cilacap Regency, Central Java Province, the Special Detachment 88 wrongfully apprehended Irfan. They beat and dragged Irfan and some other men along the street. The police forced him to show the house of Baridin, a suspect who

1 Oishimaya Sen Naga, Muslim Population by Country, accessed from https://www.worldatlas.com/articles/countries-with-the-largest-muslim-populations.html, on 22 July 2019.

2 The J.W. Marriot Hotel in Jakarta was bombed in 2005 and 2009. In 2009, the Ritz Carlton Hotel, which is situated adjacent to J.W. Marriot Hotel, was also struck by bomb.

3 In October 2002, more than 202 people were killed and over 300 injured in a bombing outside a packed tourist bar Sari and Padi Café in Legian, Bali. Over thirty of the deceased victims are British, and most of the rest are Australian. Twenty-nine suspects were arrested. Al Qaeda and local Islamic groups were blamed. The group wishes to create an Islamic super-state consisting of Malaysia, Indonesia, and the Southern Philippines. See John Richard Thackrah, Dictionary of Terrorism, $2^{\text {nd }}$ edition, London: Routledge, 2004, p. 23.

4 Ibid., see also Tempo.co, "Diduga Teroris, Warga Temanggung Ditangkap Detasemen 88", accessed from https://nasional.tempo.co/read/96142/diduga-teroris-warga-temanggung-ditangkap-detasemen-88, on March 2019. 
was also the father in law of Nordin M. Top. Nordin M. Top, a Malaysian citizen, was a top terrorist suspect in Indonesia. Iran was dragged on the street for 25 meters and finally being pushed inside the car. Inside the car, Irfan was constantly beaten by the police. When the police were aware that they wrongfully arrested Irfan, then they released him and gave him IDR500.000. In the same place, ten officers of Special Detachment 88 pointed their weapons to kindergarten students who were studying in the classes. The police snapped the teachers and students and forced them not to make any motions. The students subsequently cried and deeply traumatized. ${ }^{6}$

Another case involves Arina, the widow of Nordin M. Top who was the target of a massive search. Arina's relatives had been frequently snooped, terrorized, hunted, and apprehended by the police. Top was killed by Special Detachment 88 on September 17, 2009. However, the distresses of Arina's family were continued. The police arrested Arina. Her children were also taken with her. She was brought to Jakarta without having time to breastfeed her baby. After arriving at Jakarta, while she was still tired, she was abruptly interrogated by the police. While she breastfed her child, around 20 armed specials police surrounded her. In addition, the police force to take the DNA test of her children when the children were still crying and depressed. ${ }^{7}$

During police interrogation in Jakarta, Arina was also forced to change her legal counsel. The police provided her a lawyer who has a close connection to the Special Detachment 88. After returning to her hometown, Arina found that she lost almost all of her property and relevant documents. She got no ID card anymore. When she applied for a new ID card, the official provided her a new ID card with a new status: 'single'. Her previous marriage with Nordin M. Top was revoked, and her children were considered extramarital children. ${ }^{8}$

Since its inception soon after the Bali Bombing 2002 and become effective since 2003, the Special Detachment 88 has frequently arrested ${ }^{9}$, killed, tortured, and abused the suspects. Sometimes they get wrong suspects. Not just the terrorist suspects, in many cases, the family or surrounding relatives of suspects are also subject to inhuman and degrading treatment and punishment.

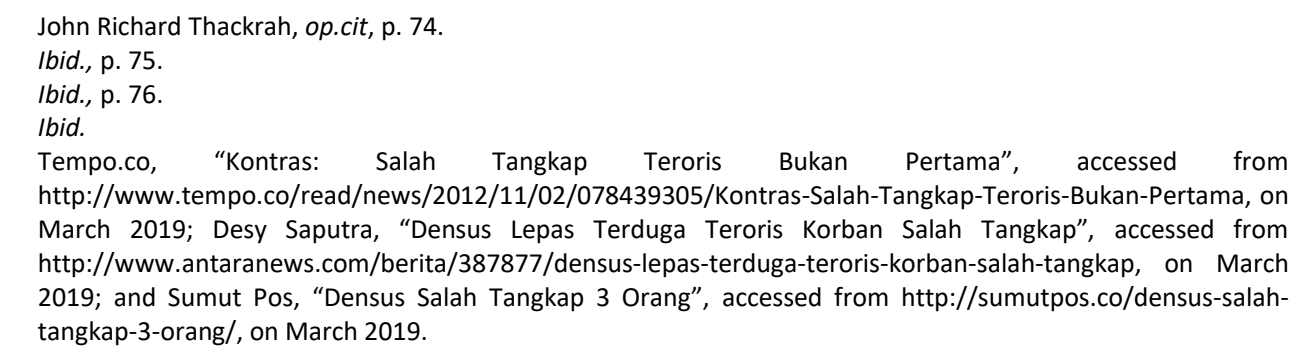
http://www.tempo.co/read/news/2012/11/02/078439305/Kontras-Salah-Tangkap-Teroris-Bukan-Pertama, on March 2019; Desy Saputra, “Densus Lepas Terduga Teroris Korban Salah Tangkap", accessed from http://www.antaranews.com/berita/387877/densus-lepas-terduga-teroris-korban-salah-tangkap, on March 2019; and Sumut Pos, "Densus Salah Tangkap 3 Orang", accessed from http://sumutpos.co/densus-salahtangkap-3-orang/, on March 2019. 
In Poso Regency, Central Sulawesi, the police wrongfully arrested 14 people from December 20 to 27, 2012. They were arrested based on the wrongful allegation of killing four polices a week before. In the detention center, they were not able to communicate, no access to the families and legal representatives. During the seven days, they were abused and tortured. Most of them got severe injuries. ${ }^{10}$ The almost similar event happened on January 2013 in Bima and Dompu Regencies, Nusa Tenggara Barat Province. There, the Special Detachment 88 wrongfully killed terrorist suspects in a massive raid. ${ }^{11}$

The continuing human rights violations and abuses committed by the Special Detachment 88 lead to protest and anger, particularly from Muslim organizations. Muslim groups have called on the National Police to dissolve the anti-terror squad in the wake of allegations that it has tortured, wrongfully arrested, or killed terrorist suspects. The Chairperson of Muhammadiyah, Din Syamsuddin, who is also the Deputy Chairperson of the MUI (Majelis Ulama Indonesia -Indonesian Muslim Clerics Council), says that the police force must change its current approach in combating terrorism as it would prove counterproductive to terrorism eradication efforts. Din and the representatives of other Islamic groups, including the Nadhlatul Ulama (NU), the Indonesian Islamic Da'wah Board (DDII -Dewan Dakwah Islamiyah Indonesia), and the Islamic Union (Persis -Persatuan Islam), reported alleged human rights abuses perpetrated by the members of the detachment against suspected terrorists. The groups claimed to have presented to the police video footage depicting men in the Detachment 88 uniforms intimidating and torturing a suspected terrorist. ${ }^{12}$

Indonesian media has also co-created 'terrorism' through labelling and haphazard reporting and articles. For instance, detik.com, an Indonesian prominent online news portal, reported a story of the raid of terrorism suspects by writing 3 Hari Operasi Penangkapan Teroris, 19 Pria Diamankan Polri ${ }^{13}$ (Three Days of Terrorist's Arrest Operation, 19 Men have been Apprehended by the Police). A popular TV Station KOMPAS put the headline Penangkapan Teroris Temanggung

10 Aldian Wahyu Ramadhan, "Polisi Bebaskan 14 Korban Salah Tangkap Kasus Poso", accessed from http://www.republika.co.id/berita/nasional/hukum/13/01/02/mg05oy-polisi-bebaskan-14-korban-salahtangkap-kasus-poso, on March 2019.

11 Ina Parlina, "Densus 88 Kills 5 More Terrorist Linked To Poso Unrest", accessed from http://www.thejakartapost.com/news/2013/01/06/densus-88-kills-5-more-terrorist-linked-poso-unrest.html, on March 2019; Tempo.co, "Keluarga Korban Salah Tembak Mengadu ke Kapolri", accessed from http://www.tempo.co/read/news/2013/01/06/058452399/Keluarga-Korban-Salah-Tembak-Mengadu-keKapolri, on March 2019.

12 The Jakarta Post, "Muslim Groups Want Densus 88 Dissolved Over Rights Abuses", accessed from http://www.thejakartapost.com/news/2013/03/01/muslim-groups-want-densus-88-dissolved-over-rightsabuses.html, on March 2019.

13 Audrey Santoso, "3 Hari Operasi Penangkapan Teroris, 19 Pria Diamankan Polri", https://news.detik.com/berita/3766794/3-hari-operasi-penangkapan-teroris-19-pria-diamankan-polri, accessed on March 2019. 
Diduga Jaringan Filipina ${ }^{14}$ (Arrest of Temanggung's Terrorists is Suspected to be Philippines Network). On 25 June 2014, the detik.com also came up with the title Sosok Terduga Teroris, Suka Pakai Celana Ngatung dan Pernah Dipenjara ${ }^{15}$ (Terrorism Suspects are Those Who Usually Wear Trouser above Their Ankles and Used to Live in Prison). The news is problematic since the media usually write the word 'terrorist' to refer to suspects, which is a violation on the presumption of innocence principle. The case has not been brought to justice yet, but the media has judged the suspects as terrorists. Media use to label them who usually wear trouser above their ankles and used to live in prison. This title, indeed, is very presumptuous, since not all people who meet the characteristics are terrorists.

Surprisingly, Indonesian higher education also involved. The State Islamic University of Sunan Kalijaga in Yogyakarta, at the beginning of 2018, issued a regulation to provide counselling program for niqab-wearing students. Yet, later this policy was revoked due to massive criticism from all over Indonesia who supported the students who wear niqab. ${ }^{16}$ Despite the fact that Indonesia is the most predominantly Muslim country in the world, the university seemed unhappy with women students who wear niqab. Supposedly, niqab is perceived to be an Arabic women Muslim wear. It has no root in Indonesian culture. Additionally, wearing niqab is associated with radicalism and religious extremism. It is incompatible with the rule and dress code of the university, which is adhered to the moderate interpretation of Islam. ${ }^{17}$

Furthermore, the BNPT (Badan Nasional Penanggulangan Terorisme -National Anti-Terrorism Agency), revealed that characteristic features of terrorists usually ${ }^{18}$ (1) always hate the state and the government and perceived the government as thaghut (idols other than Allah, the one and only God); (2) not easily socialize with other people; (3) tend to be solitaire and asocial; (4) are uncommunicative; and (5) prefer to surf to radicals contents in the internet; and (6) do not want to join collective prayer (shalat jama'ah) since they think that they are the most devout person. The BNPT's characterization of terrorist is also problematic. BNPT has

14 Kompas TV, "Penangkapan Teroris Temanggung Diduga Jaringan Filipina", accessed from https://www.kompas.tv/content/article/19908/video/berita-kompas-tv/penangkapan-teroris-temanggungdiduga-jaringan-filipina, on March 2019.

15 Detik News, "Sosok Terduga Teroris, Suka Pakai Celana Ngatung dan Pernah Dipenjara”,_accessed from https://news.detik.com/berita/d-2618343/sosok-terduga-teroris-suka-pakai-celana-ngatung-dan-pernahdipenjara, on March 2019.

16 Bambang Muryanto, "Yogya University cancels counselling program for 'niqab'-wearing students", accessed from http://www.thejakartapost.com/news/2018/03/11/yogya-university-cancels-counseling-program-forniqab-wearing-students.html, on March 2019.

17 Bambang Muryanto, "Allow students to wear the niqab, university urged", accessed from http://www.thejakartapost.com/news/2018/03/07/allow-students-to-wear-niqab-university-urged.html, on March 2019.

18 Jawa Pos, "Lima Ciri-Ciri Teroris Versi BNPT yang Pertama Baru Saja Terjadi", accessed from https://www.jawapos.com/read/2017/07/29/147464/lima-ciri-ciri-teroris-versi-bnpt-yang-pertama-baru-sajaterjadi, on March 2019. 
narrowed the characteristic of terrorist to a particular group of Muslim people, which is incorrect since terrorist can be originated from various groups and affiliations.

\section{B. Traditional Definition and Scope of Terrorism}

Defining terrorism is really a challenging job since there is no universally accepted definition of terrorism. ${ }^{19}$ Laquer $^{20}$ mentions that there will be no single definition of terrorism covering the whole pattern of terrorism in the world. The League of Nation in 1937 defines 'terrorism' as follows. ${ }^{21}$

Art. 1 "Terrorism is criminal acts directed against a State and intended or calculated to create a state of terror in the minds of particular persons, or a group of persons or the general public."

The US Department of Justice provides another definition of terrorism as follows.

"...the unlawful use of force or violence against persons or property to intimidate or coerce a government, the civilian population, or any segment thereof, in furtherance of political or social objectives..." ${ }^{22}$

Article 2 (1) of the Draft of Comprehensive Convention on International Terrorism states that ${ }^{23}$ any person commits an offence within the meaning of this Convention if that person, by any means, unlawfully and intentionally causes

(1) Death or serious bodily injury to any person;

(2) Severe damage to public or private property including a place of public use, a state or government facility, a public transportation system, an infrastructure facility of the environment; and

19 There is no internationally recognized definition of the term 'terrorism'. Global conventions deal with specific terrorist acts, such as the taking of hostages or hijacking of aircraft, and UN resolutions refer to terrorism but the meaning of the term and the subject that it characterizes is still contested. In practice, it is used to describe both violence perpetrated by a state and individuals or non-state groups, both in situations of conflict and in peacetime. Generally, the term is understood as related to politically motivated violence perpetrated to cause death or injury to civilians with the aim of intimidating a wider audience. These elements are largely reflected in national laws. However, the category of terrorism and the perpetrators can remain highly contested. States tend to characterize violence as 'terrorist' when it is perpetrated by groups considered a threat to themselves or their allies, whilst similar acts perpetrated by groups politically or ideologically close to them might be part of a 'liberation struggle'. This ambiguity is evident in how the term is applied in domestic counter-terrorism legislation. See Sara Pantuliano (et al.), "Counter-Terrorism and Humanitarian Action: Tensions, Impact and Ways Forward", HPG Policy Brief No. 43, accessed from http://www.odi.org/sites/odi.org.uk/files/odi-assets/publications-opinion-files/7347.pdf, on March 2019.

20 COT Institute for Safety, Security and Social Management, "Defining Terrorism", WP 3 Deliverable 4, October 1, 2008, accessed from http://www.transnationalterrorism.eu/tekst/publications/WP3\%20Del\%204.pdf, on March 2019.

21 Upendra D. Acharya, "War on Terror or Terror Wars: The Problem on Defining Terrorism", accessed from http://djilp.org/wp-content/uploads/2011/08/Acharya-Final.pdf, on March 2019.

22 Graeme C.S. Steven and Rohan Gunaratna, Counterterrorism: A Reference Handbook, Santa Barbara: ABC CLIO, 2004, p. 6.

23 International Law Student Association, “Appendix II: Draft comprehensive convention against international terrorism" accessed from https://www.ilsa.org/Jessup/Jessup08/basicmats/unterrorism.pdf, on March 2019. 
(3) Damage to property, places, facilities, or systems are resulting or likely to result in: significant economic loss, when the purpose of the conduct, by its nature or context, is to intimidate a population or to compel a government or an international agreement to do or abstain from doing any act.

Terrorism is a highly subjective and contested term. States and scholars may have failed to offer a universally agreed definition of terrorism. However, they do agree the four essential elements. First, terrorism is an act of violence. Second, it is deliberately undertaken. Third, its primary targets are unarmed civilians. Fourth, the last, its immediate motive is to create fear since state has a monopoly to use violence. Even though with some legally specified preconditions, scholarly definitions of terrorism identify only non-state actors as perpetrators.

In Indonesia, terrorism has no legal definition until the enactment of a special law on terrorism after the Bali Bombing. It is the Government Regulation in Lieu of Law Number 15 of 2003 and the Law Number 16 of 2003. The Government Regulation In lieu of Law Number 1 of 2002 on the Eradication of the Crime of Terrorism was issued in the reign of President Megawati Soekarnoputri under her emergency 'legislative' power. Ordinarily, the President can issue only regulations. However, Article 22 of the Constitution permits the President to issue government regulations in lieu of law. ${ }^{24}$ As required by the Constitution, the Indonesian Parliament adopted the Government Regulation in Lieu of Law Number 1 of 2002 (on April 4, 2003) into the Law Number 15 of 2003. This confirms the Government Regulation in Lieu of Law remains the anti-terrorism law in Indonesia. ${ }^{25}$

The Law does not define terrorism per se. Instead, Article 1 (1) states that the crime of terrorism is any act that fulfils the elements of an offence under the regulation. These elements are set out in Articles 6 to 23. Article 6 provides a general description of terrorism that any person who, by intention, uses violence, or threats of violence, creates a widespread atmosphere of terror/fear, or causes mass casualties, by taking the liberty or lives and property of other people, or causing damage or destruction to strategic vital objects, the environment, public facilities, or international facilities, faces the death penalty, or life imprisonment, or between 4 and 20 years' imprisonment. The Article 7 is almost identical to that of Article $6^{26}$, except that it, first, refers to an act that is intended to create terror or mass casualties, but which does not actually cause either; and, second, the maximum

24 Simon Butt, "Anti-Terrorism Law and Criminal Process in Indonesia", Background Paper No. 1. ARC Federation Fellowship 'Islam and Modernity: Syari'ah, Terrorism and Governance in South-East Asia', University of Melbourne.

25 Ibid.

26 "Anyone who intentionally uses violence or threats of violence intends to create a widespread atmosphere of terror or fear of people or cause mass casualties by seizing liberty or loss of life or property of others or to cause damage or destruction to strategic vital objects, or the environment, or public facilities, or international facilities, are punished with imprisonment for a maximum of lifetime. 
penalty available under Article 7 is life imprisonment ${ }^{27}$. Following the Law Number 15 of 2003, the government and the House of Representatives enacted the Law Number 16 of 2003, which stipulates that the Government Regulation in Lieu of Law Number 1 of 2002 on the Eradication of Terrorism was applied to Bali Bombing 2002 , or the law was applied retroactively. ${ }^{28}$

Another issue emerged when the Decree of the Constitutional Court Number013/PUU-1/2003 annuls the Anti-Terrorism Law Number 16 of 2003 that stipulates the implementation of the Anti-Terrorism Law Number 15 of 2003 was only to investigate the Bali Bombing 2002. Thus, the unfinished investigation and trials of the suspects of Bali Bombing 2002 did not have legal ground.

The latest regulations on terrorism were enacted in 2013 and 2018 respectively. They are the Law Number 9 of 2013 on the Prevention and the Eradication of Financing of Terrorism ${ }^{29}$ and also the Law Number 5 of 2018 on the Amendment on the Government Regulation in Lieu of Law Number 1 of 2002 on Eradication of Terrorism. Different o the 2002 Law, the newest 2018 law on terrorism has expanded the definition of terrorism to also cover any acts of violence/ threat that creates terror based on ideological, political, and security motives. ${ }^{30}$ Furthermore, the 2018 Law covers not only post-terrorism but also any activities constituted as pre-terrorism such as recruitment, training, disseminating radical ideology, etc.

\section{Critical Approach to Terrorism: Social Constructivism Theory}

According to social constructionists, the definition of crime varies depending on who is defining it. There are no purely objective definitions. All definitions are based on values and biased to some degree. Law describe crime as somewhat arbitrary and representing a highly selective process. ${ }^{31}$

The social constructionist is rooted in the history of critical theory. The concept of social construction is a theoretical position that cuts across a number of disciplinary and interdisciplinary fields, including sociology, psychology, psychotherapy, women studies, history and philosophy of science, narrative

\footnotetext{
Ibid.
}

28 According to the Indonesian 1945 Constitution, Article 28(i), all people could not be indicted retroactively, and this is part of inalienable rights. Therefore, the Law Number 16 of 2003 is a retroactive law that instigates legal controversy.

29 'Financing of terrorism' means, according to article 1 (1), "All measures intended to supply, to collect, to provide or to lend the fund, either directly or indirectly, known to be used for terrorist activities, terrorist organization or terrorists."

30 Terrorism is an act that uses violence or threat of violence create an atmosphere of terror or fear extends, which can cause casualties mass, and/or cause damage or destruction of strategic vital objects, living environment, public facilities, or facilities international ideological, political or security disturbance.

31 Barak G, as quoted by Henry S, "Social Construction of Crime", accessed from https://www.researchgate.net/profile/Stuart_Henry/publication/258834333_Social_Construction_of_Crime/li nks/545b0b3d0cf2c16efbbbd037/Social-Construction-of-Crime.pdf, on 2 March 2019. 
philosophy, and literary theory. Advocates of social constructionism argue that the social world exists primarily through humans' routine interaction. Humans create social reality by identifying some features of social life as significant, distinguishing those features from others, and acting as though they have a real, concrete existence. In its extreme form, social constructionism draws on the idealist/nominalist philosophical tradition that social reality does not have independent existence outside human mind. Humans interpret the world and make summary representations (images in their mind) that they believe to reflect an underlying reality. ${ }^{32}$

Studies and theoretical analyses suggest that several alternative ways of perceiving and framing terrorist images exist and that they are likely to be associated with a preference for different counter-terrorism actions. Kruglanski, Crenshaw, Post, and Victoroff (2007) suggest that four common terrorism metaphors inspire different ways of thinking about the nature of counterterrorism. Perceiving terrorism as a disease evokes the image of counter-terrorism as a search for a cure. Treating terrorism because of escalated inter-group conflict motivates the search for adequate conflict resolution strategies. Seeing terrorism as an act of war leads to a preference for fighting terrorists, who are considered soldiers of the enemy. Treating terrorist as criminals evokes a tendency to prosecute the perpetrators of the socially unacceptable and unlawful acts in order to isolate them from their potential community-based support. ${ }^{33}$

After the $11 / 9$, the word terrorism has been much exploited by politicians. It has become a primary term in central narratives of Western culture, like the terms freedom and democracy. At the same time, it is still impossible to be defined. No official and agreed definition accurately describes the term. Over the years, the act of terrorism has changed the meaning of terrorism many times. All attempts to fix a definition come to nothing. Furthermore, the meaning of the term has become even more abstract and elusive after the 11/9. ${ }^{34}$

In the political discourse, it has been used interchangeably with the term terror, which is more general. Various words have been used to describe them who commit acts of terrorism. They are radicals, fundamentalists, evil lunatics, enemies of democracy, and enemies of civilization, enemies of freedom, insurgents, tyrants, murderers, criminals, and killers who operate in shadowy networks. The definition of a terrorist has become as elusive as the term terrorism. As these vague categories are used in public discourse, it induces a climate of fear and anxiety among the Western people. This climate of fear has had a profound effect on

\footnotetext{
lbid.

33 Malgorzata Kossowska (et al.), "Stereotyped Images of Terrorists as Predictors of Fear of Future Terrorist Attacks", Behavioral Sciences of Terrorism and Political Aggression, 2010.

34 Livio Nimmer, De-Contextualization in the Terrorism Discourse: A Social Constructionist View, ENDC Proceedings, Vol. 14, 2011, pp. 223-240.
} 
public discourse, policy, and civil liberty. Then, the aims of terrorists have become a strategy of scapegoating and attaching negative labels to political dissidents, activists, and random people in the name of security and avoidance of radicalization. ${ }^{35}$

McCulloh asserts that transnational crime framework, particularly the 'war on terror', has provided a productive fiction for expanding the coercive capacities of states. The prolific invention of transnational crime worked to fill in the 'empty threat' created by the end of the Cold War. Although continuous and congruent with earlier campaigns such as the 'war on drugs' and the 'war on organized crime', the 'war on terror' has expanded the framework. The fictive nature of transnational crime in providing a pretext for other hidden agendas related to foreign and economic policy is hinted at by the similar rhetorical strategies used in these 'wars', as well as by how various 'counter' measures are developed ahead of the problems. $^{36}$

It is essential to appreciate that there is currently no internationally agreed definition of terrorism. Therefore, both academic and national definitions can be analyzed to highlight the recurring elements in the hundreds of current definitions. The definition of terrorism has a history of controversy. Simply defining it from a singular viewpoint cannot be adequate without discussing various academic approaches to the problem. The social constructionist, traditionalist, tactic, and legalistic approaches have been explained alongside existing legislation to offer a fair dimension to this study. Public fears over the mass reported global terrorist threat in the post-11/9 climate places intense demands on the need for an internationally recognized definition. The need to prosecute is hampered by historical paralysis that prevents an agreed definition. ${ }^{37}$

Defining terrorism is vital because the major risk it poses to society. Terrorism is different from other serious crimes as fanatics and those driven by an ideological purpose are less predictable. ${ }^{38} \mathrm{~A}$ comprehensive definition is necessary to account for the special provisions instigated. If the threat is overplayed, perhaps these provisions should be revised. The term 'terrorism' has become ingrained in mundane vocabulary. There is consistency in its use by news media and politics and it is recognizable by the mass. Nevertheless, its actual definition has been widely

\footnotetext{
Ibid.

36 Jude McCulloch, "Transnational Crime as Productive Fiction: beyond Transnational Crime", Social Justice, Vol. 34, No. 2, 2007, pp. 28-29.

37 Anonymous, "To What Extent is Terrorism a Social Construct?" a Doctoral Dissertation, University of Leeds, accessed from http://resources.library.leeds.ac.uk/the-final-chapter/dissertations/law/example2.pdf, on March 2019.

38 See The Definition of Terrorism A Report by Lord Carlile of Berriew Q.C. Independent Reviewer of Terrorism Legislation Presented to Parliament by the Secretary of State for the Home Department, by Command of Her Majesty March 2007, from https://assets.publishing.service.gov.uk/government/uploads/system/uploads/attachment_data/file/228856/ 7052.pdf, on March 2019.
} 
debated. Hundreds of definitions have already materialized. Schmid and Jongman found 22 definitional elements across 109 various definitions of terrorism. ${ }^{39}$ Likewise, Laqueur could pinpoint 100 definitions and concluded that the only "general characteristic generally agreed upon is that terrorism involves violence and the threat of violence". ${ }^{40}$ This adds to the controversy of defining terrorism as a separate entity, as it is not the only criminal act to do this. Accepting that terrorism has similar elements to other crimes leads one to believe that it cannot be objectively analyzed. For both legal and academic purposes, when determining an act as terrorism, one would need to "be aware that he is making a value judgment about perpetrators of the alleged act, and about the circumstances of their actions" ${ }^{41}$ This leads to a debate as to whether it is legally justified to perpetuate such moralistic terms, especially when lawful trial sets out to deal fairly with such matters.

One reason for no internationally approved definition is that some states and political leaders have had a history of engaging in terrorist activities. Even the United Nations, which consists of 192 member-states, has not proposed an agreed definition mainly because of this. ${ }^{42} \mathrm{~A}$ controversial issue pressing on definitional arguments is whether the term 'terrorism' can be applied to states. Terrorism is usually defined as non-state action but emphasize this obscure the role of the state in promoting acts of political violence. ${ }^{43}$

McQueeney affirms that terrorism is constructed through the interpretation of events, the use of claims made up of language and symbols and the work of claimsmakers to attract the public's attention and sway public opinion in support of some interests over others. Fundamental to this process is that claims-makers deploy dominant language and symbols that circulate in the culture to construct social problems. Moreover, the issues that are defined as social problems in the real world are products of ideological power struggles. ${ }^{44}$

Not only about terrorism, in United States, for example, a standard narrative about crime targets young black men living in poor urban neighborhoods as perpetrators of violent and drug-related crimes. A local context to community, crime, and fear influence the narrative. News media highlight incidents of crime, mainly when it is violent and sensational. Often, this is linked directly to the poor,

39 Schmid, A. P., Albert J. Jongman, A. J. Political terrorism: A new guide to actors, authors, concepts, databases, theories and literature, New Jersey: Transaction Books, 1988.

40 Walter Laqueur, The New Terrorism: Fanaticism and the Arms of Mass Destruction, Oxford: Oxford University Press, 1999.

41 Wilkinson in Chris Hale, et.al. Criminology, Oxford: Oxford University Press, 2005.

42 Alison Liebling, Shadd Maruna, Lesley McAra (eds). The Oxford Handbook of Criminology, $6^{\text {th }}$ edition, Oxford: Oxford University Press, 2017.

43 See Chris Hale, et.al. Criminology, Oxford: Oxford University Press, 2005.

44 Krista McQueeney, "Disrupting Islamophobia: Teaching the Social Construction of Terrorism in the Mass Madia", International Journal of Teaching and Learning in Higher Education, Vol. 26, No. 2, 2014. 
often black and Latino, neighborhoods and male. ${ }^{45}$ McCauley argues that media and politicians commonly frame terrorism as an act of war or crime. Preference for the war on terrorism is more likely when terrorists are portrayed as soldiers and terrorism as an act of war. The choice for the prosecution of guilty individuals is possible when terrorists are portrayed as criminals. This is various in target (groups or individuals) and scope (short-term or long-term strategy). ${ }^{46}$ Portrayal of terrorists as biased and irrational vs objective and rational leads people to opt for different counter-terrorism strategies. On the one hand, military response is preferred when terrorists are viewed as irrational fanatics. On the other hand, negotiations are preferred when terrorists are perceived as rational strategy. ${ }^{47}$

According to Sacco, crime, like an economic recession, is experienced as both private and public issue. For victims, a criminal offence and the resulting loss or injury presents problem of a highly personal nature. For victims and non-victims alike, however, the 'plaque of drugs', the 'random violence' and other crime problems are matters for intense public discussion and political debate. Central to the interplay between the individual's private troubles with crime and the social issue of crime is the mass media. The news media, in particular, provide an essential forum in which private difficulties are gathered up selectively, given a broader meaning, and made available for public consumption. The dynamic character of these processes and the consequences that they have for a general understanding of crime and its solution invite scrutiny. ${ }^{48}$

McQueeney further mentions that since their first encounter with the Arab world, Westerners have cast Arabs and Muslims as uncivilized and violent (Said, 1978). These controlling images of Arab and Muslim have become printed in the American imagination since 11/9. The portrayal of Middle East as a land of barbarism and tyranny and routine casting of Arabs and Muslims as terrorists are performed by the mass media to bolster oppositions between the civilized and the uncivilized and fear of the Arabs. As such, media misrepresentations can be an instrument for advancing political agendas, including war and the restriction of civil liberties. $^{49}$

Following the $11 / 9$, in public discourse, the concept of terrorism has taken a specific common-sense form. the view has become dominant in westerners thought, simply the orthodox view of terrorism. Over the years, the orthodox view

\footnotetext{
45 Gilliam. F.D. and Iyengar, S., "Prime Suspects: The Influence of Local Television News on The Viewing Public", American Journal of Political Science, Vol. 44, 2000, pp. 560 - 573.

46 Stereotyped images of terrorists as predictors of fear of future terrorist attacks. See Kossowska, Małgorzata \& Golec de Zavala, Agnieszka \& Kubik, "Stereotyped Images of Terrorists As Predictors of Fear of Futute Terrorist Attacks", Behavioral Sciences of Terrorism and Political Aggression, Vol. 2. 2010, pp. 179-197.

47 Ibid.

48 Vincent F. Sacco, "Media Construction of Crime", The Annals of the American Academy of Political and Social Sciences, Vol. 539, May 1995.

49 McQueeney, loc. cit.
} 
of terrorism has shaped both public discourse and policymakers as objective and universal. Contrary to this mainstream view, there are other ways to conceptualize terrorism. The classification of terrorism and the label of terrorists depend primarily on the point of view. After the attacks on the World Trade Center, also in response to some earlier attacks, a vivid but very oversimplified conventional wisdom has developed about contemporary terrorism that portrays the threat as both new and unfamiliar. In the orthodox view, terrorism is broadly defined as the violence by non-state actors against innocent non-combatants. ${ }^{50}$

There is an underlying presumption in both definitions that only non-state actors can commit acts of terrorism. The latter one also introduces religion and vague ideological objectives as motivators of terrorism. The notion of ideological goals is specifically vague. In addition, it could facilitate a wide range of possible interpretations of motives that cause social actors to commit acts of violence. The orthodox view describes modern terrorist's mentality as growing from an absolutist and religiously motivated worldview, which sees everything in binary categories: good or evil and us or them. Consequently, there is no possible way to come to a rational compromise or no possibility of dialogue or mutual bargaining between the sides. Peaceful and civilized discussion and persuasion of terrorists is not possible because of their absolutist and rigid principles. Thus, the proposed solution to deal with the problems that terrorism presents is to implement strict and absolutist countermeasures against those who are classified as terrorists. ${ }^{51}$

Those who commit terrorist acts are, according to the orthodox view, enemies of the democratic process and civilization. Terrorists are described as inherently evil and uncivilized. In the orthodox view, terrorist mentality is usually portrayed as unwarrantably radical and irrational in its core. In other words, terrorists are simply nihilists who are driven by abstract cruelty and hate, the shedding of all moral restraints. Terrorist acts are described as irrational not only because of their nonsensible motives but also because their acts are directed against a tendency of rational human beings to strive for order and stability. As terrorists intimidate and destabilize societies by disseminating fear, uncertainty, insecurity, and chaos, they are described as enemies of the principle of law. Their tactics rely on generating shock, fear, and surprise in societies, which strive for order and predictability, by indiscriminately attacking innocents. Furthermore, according to the orthodox view, modern terrorists show a particular kind mercilessness by using any means possible, including the possible use of weapons of mass destruction to advance their agenda against victimized societies. In the orthodox view, terrorist threat is often portrayed as an amorphous and fluid menace and terrorists as an invisible a-

Ibid.

51 Nimmer, loc. cit. 
spatial enemy. Terrorist is stateless and without territory, operating in the form of terrorist networks that transcend the borders of states. ${ }^{52}$

\section{Critical Approach to Terrorism: Guilt by Association}

Firstly, we need to deconstruct and to clarify the basic concept of 'terrorism.' This concept is essentially contested, value-based, and open to multiple interpretations in broader cultural frames. Therefore, to some extent, terrorism is in the eye of the beholder. The decision to label protagonists forms part of the political struggle over interpretation. Groups can be labeled 'terrorist', 'liberation movement, 'radical activists', 'armed rebels', 'urban guerillas' or 'extremist dissident' just as nationstates can be labelled 'terrorist' or seen as 'repressive regimes, 'authoritarian system', or 'dictatorship'. ${ }^{53}$

Guilt by association means the attribution of blame to individuals because of the people or organizations, which they associate, rather than because of any crime that they have committed. ${ }^{54}$ Guilt by association is an attractive principle to law enforcement officials concerned about preventing future harms. Without the concept of guilt by association, government officials must carry out costly investigations to catch individuals in the act of either committing a crime or conspiring to commit one. Guilt by association, by contrast, permits the government to incarcerate persons based not on their involvement in past illegal conduct and not even on their involvement in planning future crimes, but based on their affiliation or association with others who have engaged in illegal conduct. ${ }^{55}$

Guilt by association applied by a specific group to another group may be explained as a sort of social mechanism in dealing with outside forces. Marlene Young claims that societies are constructed through the development of mutually acknowledged values, reciprocal obligations, responsibilities, and social connections among individuals, which protect from threats from outside forces. Cultures consisting of social, spiritual, moral, and legal structures and functions evolve to protect individuals in their daily lives, as well as to help acutely distressed individuals.

Existential terrorism and consequent fears of the individual result in need for emotional attachment to others, which leads to the building of societies and cultures. Societies become a critical reference for establishing and re-establishing the mechanisms that help people meet their needs. Collective dynamics is a central

\footnotetext{
52 Ibid.

53 Pippa Norris, Montague Kern and Marion Just, "Framing Terrorism", accessed from http://www.hks.harvard.edu/fs/pnorris/Acrobat/Framing\%20terrorism/Chapter\%201\%20Introduction.pdf, on March 2019.

54 Anonymous,

"Gulit

by

Association,"

accessed

from

http://dictionary.reference.com/browse/guilt+by+association on March 2, 2019.

55 David Cole, "Terror Financing, Guilt by Association and the Paradigm of Prevention in the War on Terror", in Andrea Bianchi and Alexis Keller, Counter Terrorism: Democracy's Challenge, Oxford: Hart Publishing, 2008.
} 
source of help as individuals negotiate the dangers of existence. Within this context, crime, violence, war, and terrorism can be viewed as a violation of not only a legal framework but also of individual's cognitive, emotional, and physical wellbeing, of human rights and society as a whole. As a part of the replenishing what is needed, victims strive for justice.

Furthermore, the focus lies on the labelling theory. Since labelling certain action or actors as 'terrorist' carries strong normative over-tones, the social construction of reality cannot avoid being an intensely political contest. Since conceptualization is intimately linked with theory, there can be no single 'correct' definition; instead, concepts should be assessed in terms of the fruitfulness of the theoretical insights that flow from the understanding. ${ }^{56}$

Terrorism is understood here as the systematic use of coercive intimidation against civilians for political goals. This concept identifies this phenomenon by the techniques, targets, and goals; and all these attributes are regarded as necessary and sufficient for an act to qualify as terrorism. "Terrorist" is those who employ the methods of terrorism. ${ }^{57}$

Saikia and Stepanova hold that terrorism is a tactic that involves the threat and use of violence in order to achieve a political goal. This goal may be formulated in the ideological or religious term, but invariably retains a political element. However, while the political motivation of terrorism can by no means justify the violence it perpetrates, it does help to distinguish it from -and, in fact, makes it more dangerous than -everyday crime, motivated solely or primarily by material gain. To put it, if there is no political motivation behind an attack or threat of force, it can be stated that there is no terrorism involved. ${ }^{58}$

Meanwhile, Lutz and Lutz mention that terrorism involves political aims and motives. It is violent or threatens violence. It is designed to generate fear in a target audience that extends beyond the immediate victim of abuse. The force is conducted by an identifiable organization. The violence involves a non-state actor or actors as either the perpetrator, the victim of the violence or both. Finally, the acts of violence are designed to create power in situations in which power previously had been lacking. ${ }^{59}$

The fear generated by terrorism and by the possibility of victimization in an ever-widening arena is raising the social costs of the problem, in addition to the economic costs. Victims of terrorism suffer severe and long-lasting damage to their physical, mental, and emotional health. Grief and mourning may be very much a part of the experience for victims of terrorism.

Pippa Norris, Montague Kern and Marion Just, op.cit., p. 6.

Ibid., p. 5.

58 Jaideep Saikia and Ekaterina Stepanova, Terrorism Pattern of Internalization, Thousand Oaks: Sage Publishing, 2009.

59 James M. Lutz and Brenda J. Lutz, Global Terrorism, London: Routledge Taylor \& Francis, 2004. 
Terrorization is very much related to the effect of stress, particularly traumainduced stress. Children brought up in the condition of constant violence soon become drawn into the terrorist world; although not all children growing up in turmoil and violence become terrorists. Terrorism appears in waves about once every two decades or about one in every generation. Over time, the ameliorating and exacerbating conditions for a social group are a product of the social system in which they exist. People who are badly treated and unjustly punished will seek revenge. Even some whose punishment is appropriate will struggle to wreak vengeance on those who imposed that punishment ${ }^{60}$

Howard S. Becker believes that in any case, branded as deviant has significant consequences for one's further social participation and self-image. The most important effect is a drastic change in the individual's public identity. The individual can be revealed as a different kind of person. ${ }^{61}$

The recent law on terrorism in Indonesia, the Law Number 5 of 2018 has been a subject of criticism, particularly in its definition of terrorism. In the Indonesian language, it defines terrorism as an act that uses violence or threat of violence to create an atmosphere of terror or fear extends, which can cause mass-casualties, and/or cause damage or destruction of strategic vital objects, living environment, public facilities, or international facilities that have ideological, political, or security disturbance motives.

The difficulty lies in the ideological and political motives to justify such actions, to link them to any ideologies and political purposes, and to assure that any ideology or political motives that drive such crimes. Terrorism cases in Indonesia have been linked to Islamic Terrorism. People believe that terrorists belong to any Islamist or jihadist group with specific physical characteristics. This assumption is not correct. Not all terrorism cases are driven by Islamic ideology. There have been cases in Indonesia where a person committed 'lone wolf terrorism', killing and threatening people alone or only with a small number of accessories. Not to mention the practices of the state in the past resemble the practice of terrorism by arbitrarily killing, threatening, persecuting, injuring, and torturing people without proper and lawful explanation. However, since state terrorism is excluded from the definition of terrorism in Indonesian terrorism law, such practices have never defined as terrorism.

Another case of socially and politically constructed terrorism in Indonesia is the criminal and armed groups in Papua and West Papua. There are many cases where civilian armed groups in Papua killed, tortured, took hostages, and persecuted civilians as well as Indonesian national police and army. The law enforcement officers in Indonesia have rarely addressed them as a terrorist. They are labelled as

John Richard Thackrah, Dictionary of Terrorism, London: Routledge, 2004.

61 Howard S. Becker, The Outsiders: Sociology of Deviance, The Free Press, 1991. 
Kelompok Kriminal Bersenjata (Armed Criminal Group) or Kelompok Kriminal Sipil Bersenjata (Civilian Armed Criminal Group). In fact, their crimes meet the definition and scope of terrorism. ${ }^{62}$ It shows the mechanism of guilt by association and social construction theory. Terrorism and terrorist are always associated with Islamic terrorism, jihadist, Islamist, and people wearing specific Muslim wears. However, terrorism and terror do not have a single face. There are different reasons, various backgrounds, and multiple groups and individuals, which may instigate terrorism.

\section{E. Conclusion}

The language of news media and politicians express terrorism. Hundreds of definitions continue to grow into whatever shape politicians deem suitable. Fundamentally, the label of terrorism is a moral statement since no internationally agreed definition for the way society perceives the phenomenon. The need to define terrorism is explained by its inherent risk to a democratic society. Terrorism is not a two-sided label like black or white. It means that it is easy to be viewed based on political interests. Academics must include states in terrorism definitions. When issues of immorality are whitewashed and state-proofed, the completely liberal democratic system is brought into question. To conclude, terrorism is socially constructed to suit dominant groups within society. This practice will continue to prevail until academics push fair practice.

In Indonesia, terrorism is covered by the laws and judicial decisions. Yet, in many cases, terrorism is constructed by law enforcement officers, government, media, and politicians. Various constructions and narratives lead to different demeanor. The practices of civilian armed groups in Papua and Western Papua, which correspond with the methods of terrorism, so far have been excluded from the label of terrorist. It is the clear example that terrorism is socially and politically constructed. The notion of terrorism in Indonesia is only linked to Islamic terrorism and Muslim extremist groups.

Indeed, this situation leads to uncertainty of law and victimization to innocent people who have been victimized solely because of guilt by association (with any terrorist). People are victimized not because they are real terrorists but because their appearances or physical looks meet the images of terrorist that have been constructed by state and society. Nevertheless, this condition does not happen only in Indonesia. Terrorism is a crime definitely. However, it is also a narrative that has been reproduced and narrated by various actors and generations in various places and unusual circumstances.

62 See Heru Susetyo, "KKB KKSB dan Konstruksi Sosial Politik Terorisme", accessed from https://www.hukumonline.com/berita/baca/lt5ca5a938d7296/kkb--kksb--dan-konstruksi-sosial-politikterorisme-oleh--heru-susetyo/, on March 2019. 


\section{References}

\section{Books}

Bianchi, Andrea and Alexis Keller, Counter-Terrorism: Democracy's Challenge, Hart Pub, Oxford, 2008.

Steven, Graeme C.S. and Rohan Gunaratna, Counterterrorism: A Reference Handbook, ABC CLIO, Santa Barbara, 2004.

Thackrah, John Richcard, Dictionary of Terrorism, $2^{\text {nd }}$ ed., Routledge, London, 2004.

\section{Other Documents}

Acharya, Upendra D., "War on Terror or Terror Wars: The Problem in Defining Terrorism", http://djilp.org/wp-content/uploads/2011/08/Acharya-Final.pdf, accessed in March 2019.

Aldian Wahyu Ramadhan, "Polisi Bebaskan 14 Korban Salah Tangkap Kasus Poso", http://www.republika.co.id/berita/nasional/hukum/13/01/02/mg05oy-polisibebaskan-14-korban-salah-tangkap-kasus-poso, accessed on March 2019.

Anonymous, "Gulit by Association," accessed from http://dictionary.reference.com/browse/guilt+by+association on March 2019

Anonymous, "To What Extent is Terrorism a Social Construct?", Dissertation, University of Leeds, http://resources.library.leeds.ac.uk/the-finalchapter/dissertations/law/example2.pdf, accessed in March 2019.

Audrey Santoso, "3 Hari Operasi Penangkapan Teroris, 19 Pria Diamankan Polri", https://news.detik.com/berita/3766794/3-hari-operasi-penangkapan-teroris19-pria-diamankan-polri, accessed on March 2019.

Bambang Muryanto, "Allow students to wear niqab, university urged", http://www.thejakartapost.com/news/2018/03/07/allow-students-to-wearniqab-university-urged.html, accessed in March 2019.

Bambang Muryanto, "Yogya university cancels counselling program for 'niqab'wearing students", http://www.thejakartapost.com/news/2018/03/11/yogyauniversity-cancels-counseling-program-for-niqab-wearing-students.html, accessed in March 2019.

Butt, Simon, "Anti-Terrorism Law and Criminal Process in Indonesia", Background Paper No. 1. ARC Federation Fellowship 'Islam and Modernity: Syari'ah, Terrorism and Governance in South-East Asia', University of Melbourne.

СOT Institute for Safety, Security and Social Management, "Defining Terrorism", WP 3 Deliverable 4, October 1, 2008, http://www.transnationalterrorism.eu/tekst/publications/WP3\%20Del\%204.pd $\mathrm{f}$, accessed in March 2019.

Desy Saputra, "Densus Lepas Terduga Teroris Korban Salah Tangkap", http://www.antaranews.com/berita/387877/densus-lepas-terduga-teroriskorban-salah-tangkap, accessed on March 2019. 
Detik News, "Sosok Terduga Teroris, Suka Pakai Celana Ngatung dan Pernah Dipenjara", https://news.detik.com/berita/d-2618343/sosok-terduga-terorissuka-pakai-celana-ngatung-dan-pernah-dipenjara, accessed on March 2019.

Henry S., "Social Construction of Crime", 2009, https://www.researchgate.net/profile/Stuart_Henry/publication/258834333_S ocial_Construction_of_Crime/links/545b0b3d0cf2c16efbbbd037/SocialConstruction-of-Crime.pdf, accessed in March 2019.

Heru Susetyo, KKB KKSB dan Konstruksi Sosial Politik Terrorisme. https://www.hukumonline.com/berita/baca/lt5ca5a938d7296/kkb--kksb--dankonstruksi-sosial-politik-terorisme-oleh--heru-susetyo/ accessed in July 2019. accessed from http://www.ilsa.org/jessup/jessup08/basicmats/unterrorism.pdf on March 2019

Ina Parlina, "Densus 88 Kills 5 More Terrorist Linked to Poso Unrest", http://www.thejakartapost.com/news/2013/01/06/densus-88-kills-5-moreterrorist-linked-poso-unrest.html, accessed on March 2019.

Jawa Pos, "Lima Ciri-ciri Teroris Versi BNPT yang Pertama Baru Saja Terjadi", https://www.jawapos.com/read/2017/07/29/147464/lima-ciri-ciri-terorisversi-bnpt-yang-pertama-baru-saja-terjadi, accessed on March 2019.

McCulloch, Jude, "Transnational Crime as Productive Fiction: beyond Transnational Crime", Social Justice, Vol. 34, No. 2, 2007, pp. 28-29.

Kompas TV, "Penangkapan Teroris Temanggung Diduga Jaringan Filipina", https://www.kompas.tv/content/article/19908/video/berita-kompas-

tv/penangkapan-teroris-temanggung-diduga-jaringan-filipina, accessed on March 2019.

Kossowska, Malgorzata (et al.), "Stereotyped Images of Terrorists as Predictors of Fear of Future Terrorist Attacks", Behavioral Sciences of Terrorism and Political Aggression, 2010.

Leverentz, Andrea, "Narratives of Crime and Criminals: How Places Socially Construct the Crime Problem", Sociological Forum, Vol. 27, No. 2, June 2012.

McQueeney, Krista, "Disrupting Islamophobia: Teaching the Social Construction of Terrorism in the Mass Madia", International Journal of Teaching and Learning in Higher Education, Vol. 26, No. 2, 2014.

Nimmer, Livio, De-Contextualization in The Terrorism Discourse: A Social Constructionist View, ENDC Proceedings, Vol. 14, 2011, pp. 223-240, http://www.ksk.edu.ee/toimetised, accessed in March 2019.

Norris, Pippa (et al), "Framing Terrorism", http://www.hks.harvard.edu/fs/pnorris/Acrobat/Framing\%20terrorism/Chapte r\%201\%20Introduction.pdf, accessed on March 2019.

Pantuliano, Sara (et al.), "Counter-Terrorism And Humanitarian Action: Tensions, Impact And Ways Forward", HPG Policy Brief No. 43, 
http://www.odi.org/sites/odi.org.uk/files/odi-assets/publications-opinionfiles/7347.pdf, accessed in March 2019.

Sacco, Vincent F., "Media Construction of Crime", The Annals of the American Academy of Political and Social Sciences, Vol. 539, May 1995.

Sumut Pos, "Densus Salah Tangkap 3 Orang", http://sumutpos.co/densus-salahtangkap-3-orang/, accessed on March 2019.

Tempo.co, "Keluarga Korban Salah Tembak Mengadu ke Kapolri", http://www.tempo.co/read/news/2013/01/06/058452399/Keluarga-KorbanSalah-Tembak-Mengadu-ke-Kapolri, accessed on March 2019.

Tempo.co, "Diduga Teroris, Warga Temanggung Ditangkap Detasemen 88", https://nasional.tempo.co/read/96142/diduga-teroris-warga-temanggungditangkap-detasemen-88, accessed on March 2019.

Tempo.co, "Kontras: Salah Tangkap Teroris Bukan Pertama", http://www.tempo.co/read/news/2012/11/02/078439305/Kontras-Salah-

Tangkap-Teroris-Bukan-Pertama, accessed on March 2019.

The Jakarta Post, "Muslim Groups Want Densus 88 Dissolved Over Rights Abuses", http://www.thejakartapost.com/news/2013/03/01/muslim-groups-wantdensus-88-dissolved-over-rights-abuses.html, accessed on March 2019.

\section{Legal Documents}

1945 Constitution of the Republic of Indonesia [Undang-Undang Dasar Republik Indonesia Tahun 1945]

The Government Regulation on Lieu of Law Number 1 of 2002 on the Eradication of Criminal Acts of Terrorism [Peraturan Pemerintah Pengganti Undang-Undang Nomor 1 tahun 2002 Tentang Pemberantasan Tindak Pidana Terorisme]

Law Number 5 of 2018 on the Amendment to the Law Number 15 of 2003 on the Establishment of the Government Regulation in Lieu of Law Number 1 of 2002 on Eradication of Crime Acts of Terrorism to Become a Law [Undang-Undang Nomor 5 Tahun 2018 tentang Perubahan Atas Undang-Undang Nomor 15 Tahun 2003 Tentang Penetapan Peraturan Pemerintah Pengganti UndangUndang Nomor 1 Tahun 2002 Tentang Pemberantasan Tindak Pidana Terorisme Menjadi Undang-Undang] 